\title{
Oral and Dental Findings of the Longest Surviving Patient with Hoyeraal-Hreidarsson Syndrome
}

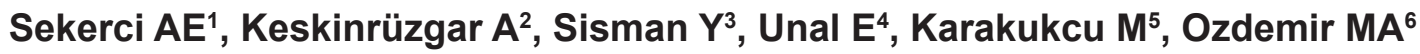

\begin{abstract}
Hoyeraal-Hreidarsson syndrome (HHS) is a severe multisystem disorder associated with premature mortality, due to bone marrow failure. Because HHS is a very rare disease and almost all cases die before 7 years of age, the dental development and dental findings of HHS patients are still not clear. According to our knowledge only twenty seven cases were reported up to now and we did not find any report focusing on the dental evaluation of HHS patients. Therefore, in this report, we aimed to present the dental findings of a twenty-year old patient with HHS.
\end{abstract}

Keywords: Hoyeraal-Hreidarsson syndrome, Dyskeratosis congenita, Aplastic anaemia, Immunodeficiency, Cerebellar hypoplasia, Oral and dental findings

${ }^{1}$ Assistant Professor

Department of Oral and Maxillofacial Radiology Dentistry Faculty, Erciyes University, Kayseri,TURKEY

${ }^{2}$ Research Assistant

Department of Maxillofacial Surgery

Faculty of Dentistry, Gaziantep University,

Gaziantep, TURKEY.

${ }^{3}$ Associate Professor

Department of Oral and Maxillofacial Radiology Faculty of Dentistry, Erciyes University, Kayseri, TURKEY.

${ }^{4}$ Department of Pediatric Hematology/Oncology Erciyes University Faculty of Medicine, Kayseri, TURKEY.

${ }^{5}$ Assistant Professor

Department of Pediatric Hematology/Oncology, Erciyes University Faculty of Medicine, Kayseri, TURKEY.

${ }^{6}$ Professor

Department of Pediatric Hematology/Oncology Erciyes University Faculty of Medicine, Kayseri, TURKEY.

\section{Contact Autbor}

Dr. Ahmet Ercan SEKERCI aercansekerci@hotmail.com

J Oral Health Comm Dent 2014;8(1)65-69

\section{INTRODUCTION}

$\mathrm{H}$ oyeraal-Hreidarsson syndrome (HHS) is a severe multisystem disorder characterized by prenatal growth retardation, microcephaly, mental retardation, psychomotor retardation, immune deficiency, facial dysmorphism, cerebellar malformation, ataxia, bone marrow failure, progressive pancytopenia, aplastic anaemia, mucocutaneous lesions, oral aphthous ulcers, aplastic alopecia, and nail dystrophy (1-6).

This syndrome causes significant mortality and morbidity with bone marrow failure and immunodeficiency are the most serious manifestation of the condition, occurring in more than $80 \%$ of patients. The natural history of HHS terminates with a death secondary to complications of bone marrow failure or infection that generally occurs in the first decade of life (7). Although the pathogenesis and genetic basis is presently unknown (8), researchers have speculated that HHS may be a severe form of X-linked dyskeratosis congenita (DKC) $(3,9,10)$.
In this study, we reported the case of a 20-year old boy who represents the longest surviving case of HHS who is still alive and described some important oral and dental findings of the syndrome that have not been previously reported.

\section{CASE REPORT}

A 20-year-old Turkish boy who is the

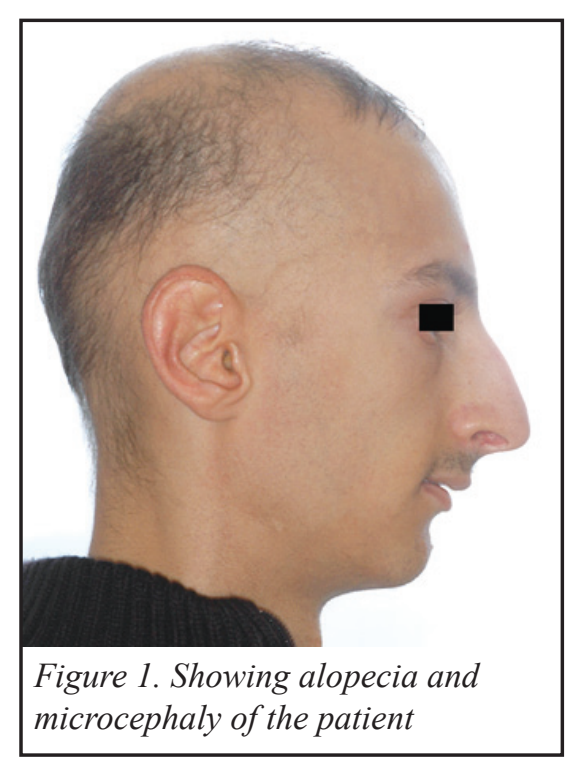




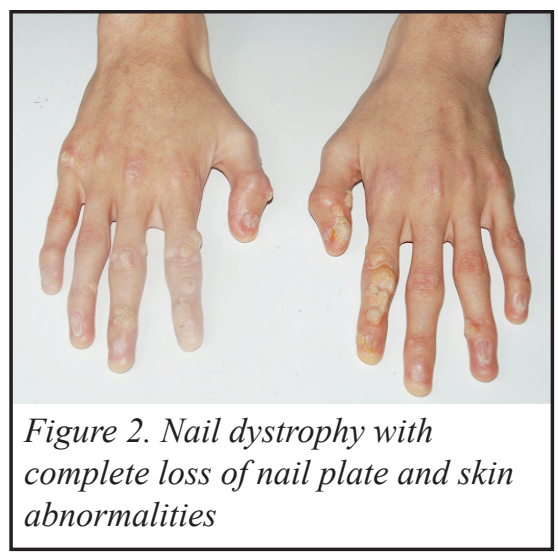

ongest surviving patient with HHS was referred to our department for treatment of his dental and periodontal problems. On physical examination, he showed microcephaly, thin face with micrognathia, retrognathia, growth failure, slow psychomotor development, high palate, low-set ears, and general muscular atrophy. He presented with speech problems and mild learning difficulties. Alopecia (figure 1) and significant nail dystrophy was also noted in the patient (figure 2). The patient also had cerebellar ataxi, nystagmus dysmetria, dysdiadochoki-

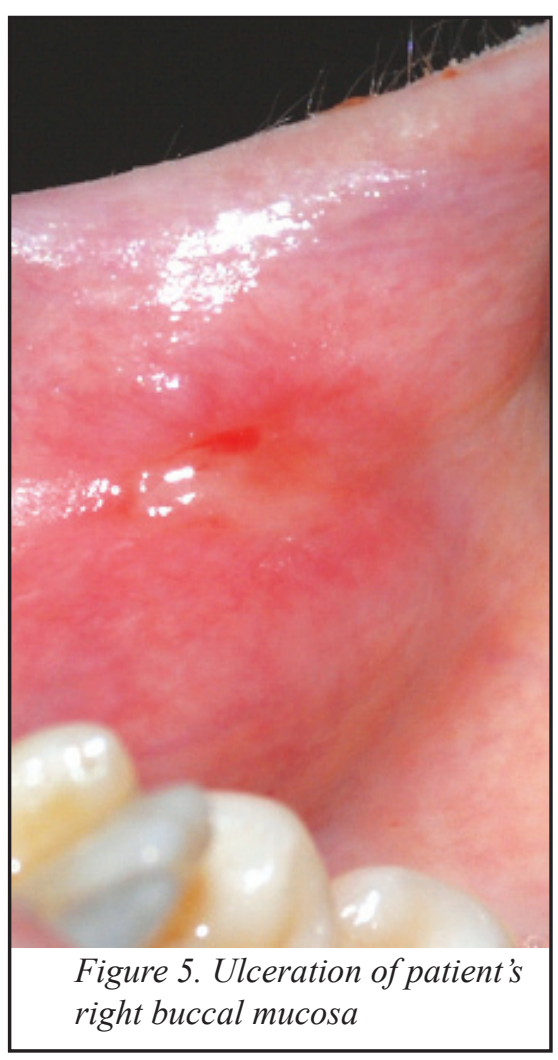

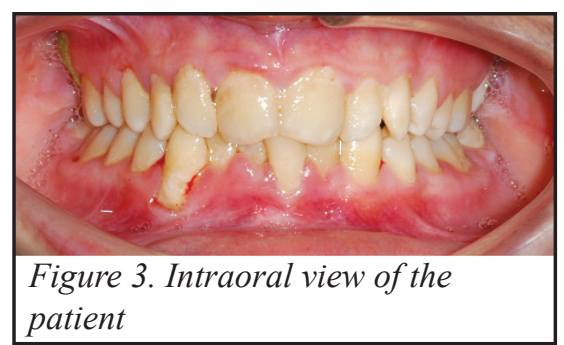

nesia, hypoplasia of the cerebellum and cerebellar vermis. Oral examination revealed local gingival recession and marginal gingivitis. His oral hygiene was insufficient with heavy plaque and considerable calculus accumulation on the teeth surfaces (figure 3). Oral findings demonstrated pale tongue (figure 4), oral ulcerations (figure 5), dental caries, short-blunted roots, gingival bleeding, and tooth mobility. Leukoplakia was not diagnosed in the oral cavity. On panoramic radiographic examination, it was observed that root development was delayed. Panoramic examination also revealed presence of retained deciduous dentition. The short and blunted roots of the mandible and maxillary teeth -especially the premolars and second molars- showed symptoms of taurodontism (figure 6). According to the patient's previous panoramic radiograph which was taken at his fifteen years, delayed teeth eruption was also discussed at that time (figure 7). In cephalometric tracing, mandibular retrognathism was found according to Steiner and Mc Namara analyses.

This case report was carried out after obtaining a written informed consent from the parents of the patient. The

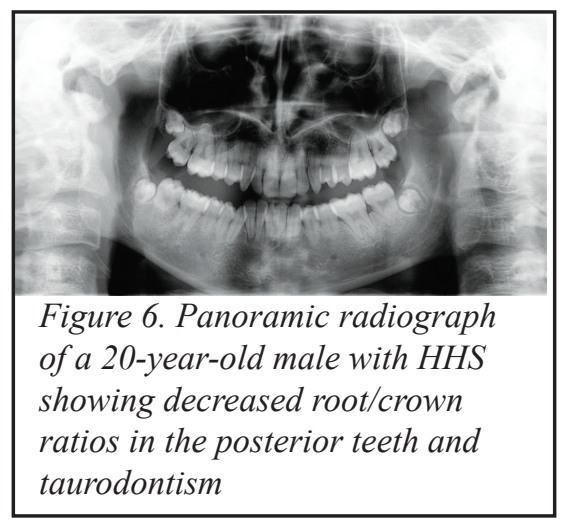

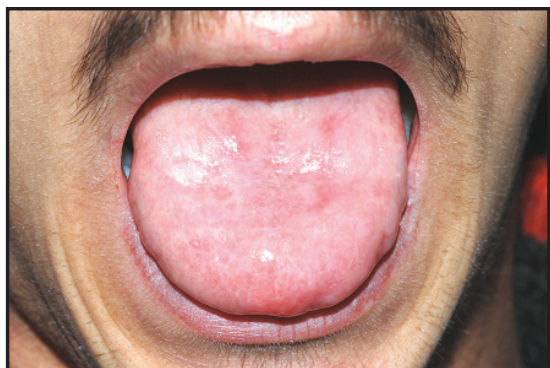

Figure 4. Photograph of dorsal surface of pale tongue

dental treatment plan included prevention protocol such as cleaning, fluoride varnish application after restorative treatment, meticulous oral hygiene instructions and the restoration of the permanent first and second molars. Gingival recessions required the consultation of a periodontist. After establishing optimal oral health, oral hygiene instructions were given to the patient and his parents. The aim of the dental treatment applied to this patient was to enable him to survive free from potential dental, gingival and acute infections. In addition, periodic follow-up visits were recommended in order to monitor oral mucosa ulcers and leukoplakic lesions.

Hematological findings showed pancytopenia and hypogammaglobulinemia now and he had requires regular transfusions. Bone marrow transplantation has not been applied since a suitable bone marrow match has not been found.

\section{DISCUSSION}

Hoyeraal-Hreidarsson syndrome (HHS) is a severe infantile variant

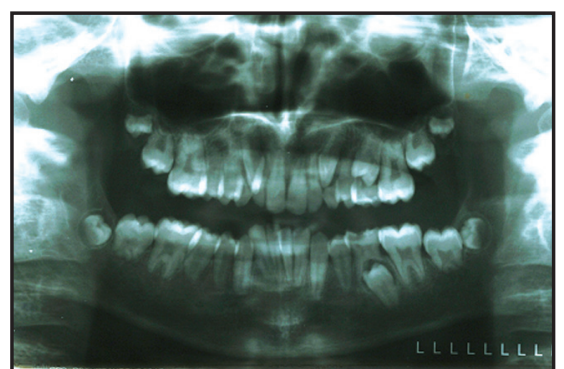

Figure 7. Patient's previous panoramic radiograph which was taken five years ago 
of X-linked DKC (3). DKC is a rare inherited bone syndrome exhibiting marked clinical and genetic heterogeneity. This syndrome is characterized by mucocutaneous abnormalities, bone marrow failure and predisposition to cancer. The main causes of mortality in DKC are bone marrow failure/immunodeficiency $(60-70 \%)$, pulmonary complications $(10-15 \%)$ and malignancy (10\%) (11). Mutations in the DKC1 gene on Xq28 have been identified in the X-linked form of DKC and in some HHS patients (1215). Clinically there appear to be three patterns of inheritance for DKC autosomal dominant, autosomal recessive and X-linked recessive (16). In order to obtain background information on our patient's condition, DNA analysis was carried out on his family. The mother had a random X-chromosome inactivation pattern. This means that she is unlikely to be a carrier for X-linked DKC. DNA samples of his father were found to be normal. DNA sample of our patient was screened for the hTR gene (mutated in autosomal dominant $\mathrm{DKC}$ ) and this again was found to be normal. Results from these analyses

\section{Table 1. Oral and dental features of all patients with HHS}

\begin{tabular}{|c|c|c|c|c|c|c|c|c|c|c|}
\hline $\begin{array}{l}\text { Numb } \\
\text { of } \\
\text { cases }\end{array}$ & $\begin{array}{l}\text { ber } \begin{array}{l}\text { Reported } \\
\text { Cases }\end{array} \\
\text { s }\end{array}$ & $\begin{array}{l}\text { Reported } \\
\text { Year }\end{array}$ & $\begin{array}{l}\text { Gender, } \\
\text { M/F }\end{array}$ & $\begin{array}{c}\text { age at } \\
\text { onset, } \\
\text { mo }\end{array}$ & $\begin{array}{c}\text { age at } \\
\text { death, } \\
\text { mo }\end{array}$ & IUGR & $\begin{array}{l}\text { micro- } \\
\text { cephaly }\end{array}$ & $\begin{array}{c}\text { Mental } \\
\text { retardation }\end{array}$ & $\begin{array}{c}\text { Oral } \\
\text { Ulcerations }\end{array}$ & $\begin{array}{c}\text { Dental } \\
\text { and oral } \\
\text { Findings }\end{array}$ \\
\hline 1 & Hoyeraal HM,1970, ( two cases) & 1970 & $\mathrm{M}$ & 9 & 23 & + & + & + & nd & nd \\
\hline 2 & & 1970 & $M$ & 5 & 43 & + & + & + & + & nd \\
\hline 3 & Hreidarsson S,1980( one case) & 1980 & M & 6 & 23 & - & + & + & + & nd \\
\hline 4 & Berthet $F, 1994$ ( one case) & 1994 & $M$ & 10 & 41 & + & + & + & - & nd \\
\hline 5 & Aalfs CM, 1995( one case) & 1995 & $M$ & 36 & nd & + & + & + & nd & nd \\
\hline 6 & Ohga S,1997( one case) & 1997 & M & 77 & 89 & + & + & + & nd & nd \\
\hline 7 & Nespoli L,1997( one case) & 1997 & M & 8 & nd & + & + & + & + & nd \\
\hline 8 & Mahmood F,1998( two cases) & 1998 & $\mathrm{~F}$ & 14 & 36 & + & + & + & + & nd \\
\hline 9 & & 1998 & $\mathrm{~F}$ & 18 & alive & + & + & + & + & nd \\
\hline 10 & Knight SW,1999 ( four cases) & 1999 & M & 18 & alive & + & nd & + & nd & nd \\
\hline 11 & & 1999 & M & 32 & 36 & + & nd & nd & nd & nd \\
\hline 12 & & 1999 & M & 18 & 32 & + & nd & nd & nd & nd \\
\hline 13 & & 1999 & M & 7 & alive & + & + & + & + & nd \\
\hline 14 & Revy P,2000( one case) & 2000 & $\mathrm{~F}$ & 2 & 48 & + & + & + & nd & nd \\
\hline 15 & Yaghmai R,2000( two cases) & 2000 & M & 8 & alive & + & + & + & + & nd \\
\hline 16 & & 2000 & M & 12 & 67 & - & + & + & nd & nd \\
\hline 17 & Akaboshi S,2000( one case) & 2000 & $\mathrm{~F}$ & 4 & alive & + & + & + & + & nd \\
\hline 18 & Cossu $\mathrm{F}, 2002$ ( one case) & 2002 & M & 9 & alive & + & + & + & + & nd \\
\hline 19 & Sznajer Y,2003(four cases) & 2003 & M & 12 & 24 & + & + & + & + & nd \\
\hline 20 & & 2003 & M & 1 & 48 & + & + & + & + & nd \\
\hline 21 & & 2003 & M & 7 & 36 & + & + & + & + & nd \\
\hline 22 & & 2003 & M & 6 & 30 & + & + & + & + & nd \\
\hline 23 & M'Kacher R,2003( one case) & 2003 & M & nd & nd & + & + & + & nd & nd \\
\hline 24 & Ozdemir MA,2004( one case) & 2004 & M & 19 & alive & + & + & + & + & nd \\
\hline 25 & Coman D, 2008( one case) & 2008 & $\mathrm{~F}$ & 24 & nd & + & nd & nd & + & nd \\
\hline 26 & Borggraefe I, 2009( two cases) & 2009 & M & 8 & 72 & + & + & + & + & nd \\
\hline 27 & & 2009 & $\mathrm{M}$ & 36 & nd & - & + & + & + & nd \\
\hline 28 & OUR PATIENT & 2010 & M & 19 & alive & + & + & + & + & \\
\hline
\end{tabular}


concluded that our patient probably represents an autosomal recessive form of DKC whose genetic basis is presently unknown. Bone marrow failure is the principal cause of early mortality with an additional predisposition to malignancy and fatal pulmonary complications. Death usually occurs as a result of pancytopenia or the malignant transformation of mucocutaneous lesions (8). According to our patient's hematological examination, pancytopenia was detected subsequently. Xlinked recessive, autosomal dominant and autosomal recessive forms of the disease are recognized. All clinicians should be aware of this rare genetic disorder so that early referral can be made and appropriate management may be applied.

The rare bone marrow failure syndrome DKC is a heritable disorder that is characterized by a triad of abnormal skin pigmentation, nail dystrophy and leukoplakic lesions in the oral cavity. Alopecia and skin lesions which entitled the name of the DKC appear later during the course of the disease (14). Our patient had abnormal skin pigmentation, nail dystrophy and alopecia consistent with these findings.

Several studies in the literature have described the oral and dental symptoms of DKC $(3,5,8,9,17-24)$. These include gingival recession, gingival bleeding, gingival inflammation with edema, alveolar bone loss, periodontitis, extensive caries, smooth atrophic tongue mucosa, leukoplakia, lichen planus, hypodontia, short blunted roots, hypocalcification and thin enamel.

The most commonly seen oral symptoms in dyskeratosis congenita are oral leukoplakia $(8,9)$ and alveolar bone loss $(23,24)$, neither were detected in our patient. The dentists must be aware for the malignant transformation of the leukoplakic lesions in patients with DKC $(25,26)$. According to our knowledge only 27 cases of HHS were reported up to now (1-
$5,7,12,14,15,19,20,27-32)$ (Table 1). The dental evaluation of these patients was not reported in any of these studies. In addition controlled studies of the associated oral and dental findings in HHS have not yet been reported. The clinical course and symptoms are still not clear because HHS is a very rare disease and almost all cases died before 7 years of age (except for case one at 12 years of age) (7). We consider that the dental and oral findings observed in our patient should be added to the previously described dental symptoms observed in HHS as they could be important in the diagnosis of the disease. The autosomal recessive form of HHS displays similar dental features of DKC. However, the $\mathrm{X}$-linked form of HHS has severe clinical symptoms which in most cases lead to early death in infancy.

Among sixteen cases had oral ulcerations only one case had no oral ulcerations and eight cases were not related to oral ulcerations. In our case the patient had oral ulceration on his right buccal mucosa.

There is no effective and curative treatment for HHS(22). Allogeneic bone marrow transplantation appears to provide a long-term solution $(33,34)$. We were able to identify only four HHS patients recorded in the literature who received a BMT $(3,14,21,32)$. Knight et al. (3) reported the use of an unrelated BMT in a boy, and M'kacher et al. (21) reported the sibling matched transplantation in a 7-year-old boy. Unfortunately, no information was provided regarding the conditioning regimens. Cossu et al. (14) reported the particular patient encountered prompt and sustained engraftment, from an HLA matched elder sibling donor, at the time of publication 1-year postBMT. Coman D et al. (32) reported a patient who was still alive during 37 months after hematopoietic stem cell transplantation. The patient reported here requires a regular transfusions replacement. Bone marrow transplantation has not been applied since a suitable bone marrow match has not been found.

In some patients standard treatments, such as chemotherapy regimens, and radiation therapy are not applicable due to the increased sensivity to these treatments (35). For these patients, preventive and interceptive precautions may be taken for early diagnosis. Patients with DKC or HHS should be kept under observation (36). In future gene therapy may provide an alternative treatment for the management of this fatal disorder (37).

\section{CONCLUSION}

HHS is a rare disorder and dentists and clinicians should be aware of its systemic and oral symptoms because of the poor prognosis. They also should be vigilant to diagnose this fatal condition in its early stages and advise appropriate haematological investigations.

It is important to be aware of the unexpected mucocutaneous malignant changes which can occur in this disorder. In addition, genetic counselling, early diagnosis and referral for the management of the dental and oral symptoms and educating the patient about the oral hygiene and dental problems seem very important.

\section{REFERENCES}

1. Ohga S, Kai T, Honda K, Nakayama H, Inamitsu T, Ueda $\mathrm{K}$, et al. What are the essential symptoms in the HoyeraalHreidarsson syndrome? Eur J Pediatr 1997;156: 80-81.

2. Akaboshi S, Yoshimura M, Hara T, et al. A case of Hoyeraal-Hreidarsson syndrome: delayed myelination and hypoplasia of corpus callosum are other important signs. Neuropediatrics 2000;31:1414.3:1-4

3. Knight SW, Heiss NS, Vulliamy TJ, Aalfs CM, McMahon C,Richond P, et al. Unexplained aplastic anaemia, immunodeficiency, and cerebellar hypoplasia (Hoyeraal-Hreidarsson syndrome) due to mutations in the dyskeratosis congenita gene. DKC1. J Haematol 1999;107: 335-39.

4. Aalfs C, v den Berg H, Barth PG, Hennekam RCM. The HoyeraalHreidarsson syndrome: the fourth case of a separate entity with prenatal growth failure, progressive pancytopenia and 
cerebellar hypoplasia. Eur J Pediatr 1995;154:304-08.

5. Hreidarsson S, Kristjansson K, Johannesson G, Johannsson JH. A syndrome of progressive pancytopenia with microcephaly, cerebellar hypoplasia and growth failure. Acta Paediatr Scand 1988;77:773-75.

6. Vulliamy T, Marrone A, Dokal I, Mason PJ. Association between aplastic anaemia and mutations in telomerase RNA. Lancet 2002;359:2168-70.

7. Ozdemir MA, Karakukcu M, Kose M, Kumandas S, Gumus H. The longest surviving child with Hoyeraal-Hreidarsson syndrome. Haematologica 2004;89: ECR38.

8. Dokal I. Inherited aplastic anaemia. Hematol J 2003;4:3-9.

9. Heiss NS, Knight SW, Vulliamy TJ, Klauck SM, Wiemann S, Mason PJ, et al. X-linked dyskeratosis congenita is caused by mutations in a highly conserved gene with putative nucleolar functions. Nat Genet 1998;19:32-38.

10. Pearson T, Curtis F, Al-Eyadhy A, et al. An intronic mutation in DKC1 in an infant with Hoyeraal-Hreidarsson syndrome. Am J Med Genet A 2008;146A:2159-61.

11. Walne AJ, Dokal I. Advances in the understanding of dyskeratosis congenita. Br J Haematol 2009;145(2):164-72.

12. Yaghmai R, Kimyai-Asadi A, Rostamiani K, Heiss, NS, Poustka, A., Eyaid, W, et al. Overlap of dyskeratosis congenita with the Hoyeraal-Hreidarsson syndrome. J Pediatr 2000;136:390-393.

13. Heiss NS, Megarbane A, Klauck SM, Kreuz FR, Makhoul E, Majewski F, et al. One novel and two recurrent missense DKC1 mutations in patients with dyskeratosis congenital (DKC). Genet Couns 2001;12:129-36.

14. Cossu F, Vulliamy TJ, Marrone A, Badiali M, Cao A, Dokal I. A novel DKC1 mutation, severe combined immunodeficiency (T+B-NK- SCID) and bone marrow transplantation in an infant with HoyeraalHreidarsson syndrome. $\mathrm{Br} J$ Haematol 2002;119:765-68.

15. Sznajer Y, Baumann C, David A, Journel $\mathrm{H}$, Lacombe $\mathrm{D}$, Perel $\mathrm{Y}$, et al. Further delineation of the congenital form of X-linked dyskeratosis congenita
(Hoyeraal-Hreidarsson syndrome). Eur $J$ Pediatr 2003;162:863-67.

16. Alter BP. Inherited bone marrow failure syndromes. In: Nathan D, Orkin SH, Ginsburg D, Look AT, eds. Hematology of infancy and childhood, 6th edn. Saınders: Philadelphia, PA, 2003:pp. 281-365.

17. Sirinavin C, Trowbridge AA. Dyskeratosis congenita: clinical features and genetic aspects: report of a family and review of the literature. J Med Genet 1975;12: 339-54.

18. Loh HS, Koh ML, Giam YC. Dyskeratosis congenita in two male cousins. BrJOral Maxillofac Surg 1987;25:492-99.

19. Berthet F, Tuchschmid P, Boltshauser E, Seger RA. The Hoyeraal-Hreidarsson syndrome: don't forget the associated immunodeficiency. Eur J Pediatr 1995;154:998.

20. Kirwan M, Dokal I. Dyskeratosis congenita: a genetic disorder of many faces. Clin Genet 2008;73:103-12.

21. M'Kacher R, Laithier V, Valent $A$, et al. Sensitivity to radiation and alkylating agent of peripheral lymphocytes and fibroblasts in a Hoyeraal-Hreidarsson syndrome patient. Pediatr Hematol Oncol 2003;20:651-56.

22. Brown CJ. Dyskeratosis congenita: report of a case. Int J Paediatr Dent 2000;10(4):328-34.

23. Yavuzyilmaz E, Yamalik N, Yetgin $\mathrm{S}$, et al. Oral-dental findings in dyskeratosis congenita. J Oral Pathol Med 1992;21:280-84.

24. Wald C, Diner H. Dyskeratosis congenita with associated periodontal disease. Oral Surg Oral Med Oral Pathol 1974;37:73644

25. Tanaka A, Kumagai S, Nakagawa K, Yamamoto E. Cole-Engman syndrome associated with leukoplakia of the tongue: a case report. J Oral Maxillofac Surg 1999;57:1138-41.

26. Marrone A, Dokal I. Dyskeratosis congenita: a disorder of telomerase deficiency and its relationship to other diseases. Expert Rev Dermatol 2006;1:463-79.

27. Hoyeraal HM, Lamvik J, Moe PJ. Congenital hypoplastic thrombocytopenia and cerebral malformations in two brothers. Acta Paediatr Scand
1970:59:185-91.

28. Berthet F, Caduff R, Schaad UB, et al. A syndrome of primary combined immunodeficiency with microcephaly, cerebellar hypoplasia, growth failure and progressive pancytopenia. Eur J Pediatr 1994;153:333-38.

29. Nespoli L, Lascari C, Maccario R, et al. The Hoyeraal-Hreidarsson syndrome: the presentation of the seventh case. Eur $J$ Pediatr 1997;156:818-20.

30. Mahmood F, King MD, Smyth OP, et al. Familial cerebellar hypoplasia and pancytopenia without chromosomal breakages. Neuropediatrics 1998;29:30206.

31. Revy P, Busslinger M, Tashiro K, et al. A syndrome involving intrauterine growth retardation, microcephaly, cerebellar hypoplasia, B lymphocyte deficiency, and progressive pancytopenia. Pediatrics 2000;105:E39.

32. Coman D, Herbert A, McGill J, Lockwood L, Hallahan A.Unrelated cord blood transplantation in a girl with HoyeraalHreidarsson syndrome. Bone Marrow Transplant 2008;42(4):293-294.

33. Rocha V, Devergie A, Socié G, Ribaud $\mathrm{P}$, Espérou $\mathrm{H}$, Parquet $\mathrm{N}$, et al. Unusual complications after bone marrow transplantation for dyskeratosis congenita. Br J Haematol 1998;103(1):243-48.

34. Langston AA, Sanders JE, Deeg HJ, Crawford SW, Anasetti C, Sullivan KM, et al. Allogeneic marrow transplantation for aplastic anaemia associated with dyskeratosis congenita. $\mathrm{Br} \mathrm{J}$ Haematol 1996;92(3):758-65.

35. M'kacher R, Laithier V, Valent A, Delhommeau F, Violot D, Deutsch E, et al. Sensitivity to radiation and alkylating agent of peripheral lymphocytes and fibroblasts in a Hoyeraal-Hreidarsson syndrome patient. Pediatr Hematol Oncol 2003:20(8):651-56.

36. Handley TP, McCaul JA, Ogden GR. Dyskeratosis congenita. Oral Oncol 2006;42:331-36.

37. AuluckA. Dyskeratosis congenita. Report of a case with literature review.Med Oral Patol Oral Cir Bucal 2007;12(5):E369373. 